\title{
Zinc as an adjunct to antibiotics for the treatment of severe pneumonia in children $<5$ years: a meta-analysis of randomised-controlled trials
}

\author{
Hong-Tao Tie ${ }^{1, \dagger}$, Qi Tan ${ }^{2, \dagger}$, Ming-Zhu Luo ${ }^{2}$, Qiang $\mathrm{Li}^{1}$, Jia-Lin $\mathrm{Yu}^{2 *}$ and Qing-Chen Wu ${ }^{1 *}$ \\ ${ }^{1}$ Department of Cardiothoracic Surgery, The First Affiliated Hospital of Chongqing Medical University, Chongqing 400016, \\ People's Republic of China \\ ${ }^{2}$ Department of Neonatology, The Children's Hospital of Chongqing Medical University, Chongqing 400016, People's Republic \\ of China
}

(Submitted 23 July 2015 - Final revision received 11 December 2015 - Accepted 15 December 2015)

\section{Abstract}

The effect of $\mathrm{Zn}$, as an adjunct to antibiotics, on the treatment of severe pneumonia in young children is still under debate; therefore, we performed a meta-analysis to evaluate the therapeutic role of $\mathrm{Zn}$ for severe pneumonia in children younger than 5 years. PubMed, Cochrane library and Embase databases were systematically searched from inception until October 2015 for randomised-controlled trials (RCT) that assessed the effect of $\mathrm{Zn}$ as an adjunct to antibiotics for severe pneumonia. Random-effects model was used for calculating the pooled estimates, and intention-to-treat principle was also applied. Nine RCT involving 2926 children were included. Overall, the pooled results showed that adjunct treatment with $\mathrm{Zn}$ failed to reduce the time to recovery from severe pneumonia (hazard ratios (HR) $=1.04 ; 95 \% \mathrm{CI} 0.90$, $\left.1.19 ; I^{2}=39 \% ; P=0.58\right)$, hospital length of stay ( $\left.\mathrm{HR}=1.04 ; 95 \% \mathrm{CI} 0.83,1.33 ; I^{2}=57 \% ; P=0.74\right)$, treatment failure (relative risk $(\mathrm{RR})=0.95$; $95 \%$ CI $\left.0.79,1.14 ; I^{2}=20 \% ; P=0.58\right)$ or change of antibiotics (RR $=1.07 ; 95 \%$ CI $\left.0.79,1.45 ; I^{2}=44 \% ; P=0.67\right)$. In addition, continuous outcomes were consistent while meta-analysed with standard mean difference, and all outcomes remained stable in intention-to-treat analysis. No significant differences were observed in the two groups between death rate, adverse events or recovery times of severe pneumonia indicators. Our results suggested that adjunct treatment with $\mathrm{Zn}$ failed to benefit young children in the treatment of severe pneumonia. Considering the clinical heterogeneity, baseline characteristics of children, definition of severe pneumonia and Zn supplement way should be taken into consideration in future research. This study was registered at PRESPERO as CRD42015019798.

Key words: Children: Meta-analyses: Severe pneumonia: Zinc

Pneumonia is a leading disease and cause of death in children under 5 years in developing countries ${ }^{(1)}$. It is reported that $14.9 \%$ of 6.3 million deaths of children $<5$ years old were caused by pneumonia worldwide ${ }^{(2)}$. With advances in medicine, economy and society, pneumonia with diarrhoea and measles was responsible for half of the reduction in mortality of children under 5 years from 2000 to $2013^{(2)}$. Although great progress was achieved, only a few countries could reach the goal of Millennium Development Goal 4 to reduce under 5 child mortality by two-thirds between 1990 and 2015, and pneumonia is still the leading cause of child mortality ${ }^{(3)}$. Therefore, intensive effort should be made in the research of pneumonia.

Under-nutrition has been reported to be strongly associated with impaired immune response, ${ }^{(4)}$ and it has been proven to be responsible for greater severity of pneumonia, prolonged course of disease and increased mortality of pneumonia ${ }^{(5)}$.
$\mathrm{Zn}$, as an important micro-element, has an essential role in cellular growth and immune defence, and its deficiency is associated with significant increased susceptibility to various infection pathogens ${ }^{(6-8)}$. In a randomised-controlled trial (RCT), Brooks et $a l .{ }^{(9)}$ first found that adjunct treatment with $\mathrm{Zn}$ could reduce the duration of syndromes of severe pneumonia and hospital length of stay (HLOS) in 270 children. This promising finding was consistently confirmed by three other RCT ${ }^{(10,11)}$. However, the study conducted by Wadhwa et al. ${ }^{(11)}$ demonstrated that only very severe pneumonia rather than all severe pneumonia could benefit from Zn. In addition, a relatively large-sample RCT with 610 children found that $\mathrm{Zn}$ supplement could reduce the duration of severe pneumonia and the incidence of treatment failure only marginally but not statistically significantly ${ }^{(12)}$. Moreover, some other RCT suggested that adjunct treatment with $\mathrm{Zn}$ failed to show any beneficial effect in children with severe pneumonia ${ }^{(13-17)}$.

Abbreviations: HLOS, hospital length of stay; RCT, randomised-controlled trial; RR, relative risk; HR, hazard ratio; SMD, standard mean difference; LRTI, lower respiratory tract infection.

* Corresponding authors: J.-L. Yu, fax +86023 63635567, email yujialin486@sohu.com; Q.-C. Wu, fax +8602368811360, email qcwucq@163.com

$\dagger$ These authors contributed equally to the study. 
Given the controversial effect of $\mathrm{Zn}$ and accumulating evidence from RCT, a meta-analysis is warranted ${ }^{(12)}$. We, therefore, performed a meta-analysis to evaluate the effect of $\mathrm{Zn}$ as an adjunct to antibiotics in children with severe pneumonia.

\section{Methods}

This study was conducted and reported in adherence to the Preferred Reporting Items for Systematic Reviews and Meta-analysis statement ${ }^{(18)}$ (online Supplementary Material). PROSPERO database registration: CRD42015019798, http:// www.crd.york.ac.uk/PROSPERO/

\section{Literature search and search strategy}

PubMed, Cochrane library and Embase databases were systematically searched (last search date: October 2015), with the search strategy conducted by combining MeSH terms and free terms related to severe pneumonia, children and $\mathrm{Zn}$. No limitation was imposed. To avoid missing potentially relevant RCT, the reference lists of the retrieved studies and relevant reviews were manually searched. Conference abstracts that met the inclusion criteria were also eligible. Two investigators performed the study selection independently, and any disputes were solved by discussion and judged by the third investigator.

\section{Inclusion criteria}

Inclusion criteria were as follows: (1) population: children $<5$ years of age with severe pneumonia; (2) intervention: standard antibiotics treatment with $\mathrm{Zn}$ supplementation; (3) comparative intervention: standard antibiotics treatment; (4) study design: RCT.

\section{Data extraction and outcome measure}

Data extraction was performed by two investigators using a pre-designed Excel sheet. The extracted information was as follows: first author, publication year, location, recruitment period, sample size, children age, serum Zn concentration at admission, percentage of male, percentage of wheezing, standard antibiotics therapy, intervention of $\mathrm{Zn}$, intervention of control and reported outcomes. Corresponding authors were contacted repeatedly while essential data were not available. The extracted information was collated by two investigators and rechecked by the third investigator.

The primary outcomes were the time to recovery from severe pneumonia, HLOS, change of antibiotics and treatment failure. Secondary outcomes included time to recovery from severe pneumonia indicators (tachypnoea, hypoxaemia, chest indrawing and fever), the death rate and adverse events (vomiting and deterioration).

\section{Assessment for risk of bias}

Risk of bias was evaluated by two authors in adherence to the guideline of Cochrane handbook for systematic review of interventions $^{(19)}$, and assessment items included selection bias, detection bias, reporting bias, blinded bias, outcome assessment bias and some other potential bias. Each item was assigned a value of 'high', 'unclear" or 'low', and the pooled risk of bias for one study was regarded as high (high risk of bias in one or more items), unclear (low or unclear risk of bias in all items) or low (low risk of bias in all items) ${ }^{(20)}$.

\section{Statistical analyses}

Relative risks (RR) with $95 \%$ CI were used for calculating the pooled estimate of dichotomous outcomes. Standard mean differences (SMD) with 95\% CI were used for calculating the pooled estimate of continuous outcomes. Continuous outcomes of time to recovery and HLOS were treated as time-to-event data and expressed as hazard ratios (HR) with $95 \%$ CI in some studies, and thus HR with $95 \%$ CI were also used to pool the results. For continuous data reported as medians with ranges, we used an elementary inequality and approximation to estimate the means and related variances ${ }^{(21)}$. Random-effects model was used in all meta-analyses. The $Q$ test and $I^{2}$ statistic were applied to assess the heterogeneity among studies. It was perceived to have high heterogeneity $\left(I^{2} \geq 75 \%\right)$, moderate heterogeneity $\left(50 \% \leq I^{2}<75 \%\right)$ and low heterogeneity $\left(25 \leq I^{2}<50 \%\right)^{(22)}$. Sensitivity analysis was performed by excluding one study in each turn and pooling the remaining ones, to detect the influence of a single study on the overall estimate. In addition, intention-to-treat analysis was also conducted to avoid bias from missing participants. In intention-totreat analysis, we assumed that all the missing participants did not experience the event for dichotomous data and imputed data of missing participants as the average difference according to control and Zn group separately for continuous data. We did not assess publication bias because fewer than ten studies were included. Review Manager version 5.1 (The Cochrane Collaboration, Software Update) was used for all statistical analyses and risk of bias. A value of $P<0.05$ was considered statistically significant, and $P<0 \cdot 1$ for the significance level of the $Q$ test.

\section{Results}

\section{Literature search}

Study selection and identification process are shown in Fig. 1. Through initial database search, 333 articles were identified after eliminating eighty-two duplications. A total of thirteen studies remained after screening titles/abstracts. Among the thirteen studies, four were excluded, of which one ${ }^{(23)}$ was an advanced abstract of an included study, two ${ }^{(24,25)}$ focused on children with severe acute lower respiratory tract infection (LRTI) but not severe pneumonia and one ${ }^{(26)}$ used the same data from the included trial. Finally, nine RCT ${ }^{(9-17)}$ were included.

\section{Baseline characteristics and risk of bias}

Baseline characteristics of included RCT are summarised in Table 1. The nine studies were published between 2004 and 2014, and all were conducted in developing countries. The sample sizes varied from 117 to 610, with a total of 2926. Severe pneumonia was defined mainly based on clinical syndromes 
415 articles identified initially: PubMed (150), Embase (198), and Cochrane library (67)

82 excluded for duplications

333 articles for first screening

320 excluded based on titles and abstracts

13 articles for further screening

4 excluded for the following reasons 1 advance abstract of included study 2 severe acute LRTI

1 the same data from the included trial

9 RCT included in the meta-analysis

Fig. 1. Flowchart of study screening in this meta-analysis. LRTI, lower respiratory tract infection; $\mathrm{RCT}$, randomised-controlled trial.

and signs according to the WHO criteria. The detailed definitions of severe pneumonia and outcomes are listed in online Supplementary Table S1. The intervention of Zn or placebo was given accompanied with standard antibiotics therapy. Children received $20 \mathrm{mg}$ of $\mathrm{Zn}$ or placebo/d in five studies ${ }^{(9,12,14,16,17)}$, whereas in other three studies ${ }^{(11,13,15)} 10 \mathrm{mg}$ of $\mathrm{Zn}$ or placebo was given for children $<12$ months and $20 \mathrm{mg}$ for children $\geq 12$ months. In the remaining one, $\mathrm{Zn}$ was given at a dose of $2 \mathrm{mg} / \mathrm{kg}$ per $\mathrm{d}$, with a maximum of $20 \mathrm{mg} / \mathrm{d}^{(10)}$. The supplementation duration was $5-14 \mathrm{~d}$ or until discharge from a hospital. For primary outcomes, eight studies ${ }^{(9,10,12-17)}$ reported time to recovery from severe pneumonia, with five ${ }^{(9,12-15)}$ reporting $\mathrm{HR}$ and $95 \% \mathrm{CI}$; five $\mathrm{(}^{(9,10,14-16)}$ reported HLOS, with three ${ }^{(9,14,15)}$ reporting $\mathrm{HR}$ and $95 \% \mathrm{CI}$; six ${ }^{(9,12,14-17)}$ reported treatment failure; and five (9,12,14,16,17) reported change of antibiotics.

The risk of bias of nine RCT is shown in Fig. 2. Risk of bias of allocation concealment was unclear in one study ${ }^{(9)}$, as there was no detailed description of the allocation methods. In addition, risk of bias was rated as unclear in detection bias because whether investigators, study nurses and caretakers were masked or not was not stated ${ }^{(16)}$

\section{Primary outcomes}

Compared with children in the control group, those who received $\mathrm{Zn}$ supplementation needed a similar period of time to recovery from severe pneumonia (HR $=1 \cdot 04 ; 95 \% \mathrm{CI} 0 \cdot 90,1 \cdot 19$; $I^{2}=39 \% ; P_{H}=0 \cdot 16 ; P=0.58 ;$ Fig. 3$)$ and HLOS (HR $=1.04 ; 95 \%$ CI $0.82,1.33 ; I^{2}=57 \% ; P_{H}=0.10 ; P=0.74 ;$ Fig. 3$)$. No significant difference between $\mathrm{Zn}$ and placebo groups was found while analysing by pooling with SMD and 95\% CI (Table 2). In addition, no significant difference between the two groups was observed in risks of treatment failure $(\mathrm{RR}=0.95 ; 95 \% \mathrm{CI} 0.79$, $1.14 ; I^{2}=20 \% ; P_{H}=0.28 ; P=0.58$; Fig. 3$)$ or change of antibiotics (RR $=1.07 ; 95 \%$ CI $0.79,1.45 ; I^{2}=44 \% ; \quad P_{H}=0.13$; $P=0 \cdot 67$; Fig. 3).
The primary outcomes were consistently non-significant when intention-to-treat analysis was used (online Supplementary Table S2). Moreover, sensitivity analysis also confirmed consistency and robustness of the pooled results (Table 3).

\section{Secondary outcomes}

Time to recovery from severe pneumonia indicators. The results by pooling $\mathrm{HR}$ with $95 \% \mathrm{CI}$ manifested that adjunct treatment with $\mathrm{Zn}$ could not decrease time to recovery from tachypnoea $\left(\mathrm{HR}=1.04 ; 95 \%\right.$ CI $0.82,1.33 ; I^{2}=65 \% ; P_{H}=0.06$; $P=0.74$; Fig. 4), hypoxaemia (HR=1.07; 95\% CI 0.89, 1.29; $I^{2}=28 \% ; \quad P_{H}=0.25 ; \quad P=0.49 ; \quad$ Fig. $\left.\quad 4\right), \quad$ chest indrawing $\left(\mathrm{HR}=1.07 ; 95 \%\right.$ CI $0.80,1.45 ; I^{2}=58 \% ; P_{H}=0.12 ; P=0.64 ;$ Fig. 4) or fever (HR =0.97; 95\% CI 0.82, 1.16; $I^{2}=0 \% ; P_{H}=0.66$; $P=0.77$; Fig. 4). In addition, these results were consistently nonsignificant while analysed by SMD and 95\% CI (Table 2).

Death rate and adverse events. Excluding children with HIV in one study ${ }^{(11)}$, ten of 905 children in the Zn group and fifteen of 904 in the control group died, and the pooled RR was 0.69 (95\% CI $0.31,1.52 ; I^{2}=0 \% ; P_{H}=0.83 ; P=0.36$; Fig. 5 ) for the death rate. The adverse effects were also evaluated, and the results revealed that adjunct treatment with $\mathrm{Zn}$ was not associated with risk of clinical deterioration $(\mathrm{RR}=0.89 ; 95 \% \mathrm{CI} 0.59$, $1.34 ; I^{2}=0 \% ; P_{H}=0.55 ; P=0.57 ;$ Fig. 5 ) or vomiting (RR=1.58; $95 \%$ CI $0.99,2.51 ; P=0.05 ;$ Fig. 5). Consistently, non-significant differences were observed when analysed by intention-to-treat analysis (online Supplementary Table S2).

\section{Discussion}

\section{Main findings}

Our meta-analysis of nine RCT with 2926 cases assessed the effect of $\mathrm{Zn}$ as an adjunct to antibiotics in children with severe pneumonia. The results suggested that adjunct treatment with $\mathrm{Zn}$ failed to reduce time to recovery from severe pneumonia, HLOS, treatment failure or change of antibiotics. In addition, adjunct treatment with $\mathrm{Zn}$ was not associated with reduced death rate, adverse events or time to recovery from severe pneumonia indicators, including tachypnoea, hypoxaemia, chest indrawing and fever. The continuous outcomes remained consistent when meta-analysed by pooling SMD and 95\% CI, and all outcomes remained stable in the intention-to-treat analysis.

\section{Comparison with previous studies}

A meta-analysis by Das et al. ${ }^{(27)}$ indicated that no evidence supported the efficacy of $\mathrm{Zn}$ as an adjunct to antibiotic in the treatment of severe acute LRTI. The relative broad scope of LRTI could certainly contribute to substantial clinical heterogeneity, and it might be associated with the significant heterogeneity (time to recovery from severe illness: $I^{2}=82 \%$, HLOS: $\left.I^{2}=82 \%\right)$. As only a few studies assessed the effect of $\mathrm{Zn}$ as an adjunct to antibiotic for the treatment of LRTI, we defined our inclusion criteria as severe pneumonia rather than LRTI, to 
Table 1. Baseline characteristics of the included randomised-controlled trials (RCT) (Mean values and mean differences (MD); medians and interquartile ranges (IQR))

\begin{tabular}{|c|c|c|c|c|c|c|c|}
\hline \multirow[b]{2}{*}{ First author year } & \multirow[b]{2}{*}{ Country Period } & \multicolumn{2}{|l|}{$\mathrm{Zn} /$ control } & \multirow[b]{2}{*}{ Standard antibiotics therapy } & \multirow[b]{2}{*}{ Intervention of $\mathrm{Zn}$} & \multirow[b]{2}{*}{ Control } & \multirow[b]{2}{*}{ Reported outcomes } \\
\hline & & $\begin{array}{l}\text { Number of children } \\
\text { Age (months) } \\
\text { Serum Zn }(\mu \mathrm{mmol} / \mathrm{l})\end{array}$ & $\begin{array}{l}\text { Wheezing (\%) } \\
\text { Male }(\%)\end{array}$ & & & & \\
\hline Basnet $2012^{(12)}$ & $\begin{array}{l}\text { Nepal } \\
8 \text { January } 2006- \\
30 \text { June } 2008\end{array}$ & $\begin{array}{l}\text { 305/305 } \\
\quad 7.8(\mathrm{MD} 6 \cdot 0) / 7 \cdot 1 \text { (MD 5.6) } \\
\quad \mathrm{NR}\end{array}$ & $\begin{array}{l}81 \cdot 6 / 82 \cdot 9 \\
59 \cdot 2 / 63 \cdot 6\end{array}$ & $\begin{array}{l}\text { Benzyl penicillin + gentamicin } \\
\text { intravenously until clinical } \\
\text { improvement, and then } \\
\text { oral amoxicillin for a total } \\
\text { duration of } 10 \mathrm{~d}\end{array}$ & $\begin{array}{l}10 \mathrm{mg}(2-11 \text { months }) / \\
20 \mathrm{mg}(>11 \text { months }) / \mathrm{d} \\
\text { until discharge or for a } \\
\text { maximum of } 14 \mathrm{~d}\end{array}$ & Placebo & $\begin{array}{l}\text { Time to recovery from severe } \\
\text { pneumonia, treatment failure } \\
\text { and vomiting }\end{array}$ \\
\hline Bose $2006^{(14)}$ & $\begin{array}{l}\text { India } \\
15 \text { September 2003- } \\
31 \text { August } 2004\end{array}$ & $\begin{array}{l}\text { 150/150 } \\
9.9(\mathrm{MD} \mathrm{6} 61) / 9.1 \text { (MD 5.7) } \\
11.0(\mathrm{MD} \mathrm{2} 2) / 10.9(\mathrm{MD} \mathrm{2} \cdot 4)\end{array}$ & $\begin{array}{l}62 \cdot 7 / 62 \cdot 4 \\
71 \cdot 3 / 67 \cdot 3\end{array}$ & $\begin{array}{l}\text { Benzylpenicillin + gentamicin/ } \\
\text { cloxacillin and gentamicin } \\
\text { (staphylococcal } \\
\text { pneumonia) intravenously }\end{array}$ & $\begin{array}{l}20 \mathrm{mg} / \mathrm{d} \text { until discharge or } \\
\text { for a maximum of } 14 \mathrm{~d}\end{array}$ & Placebo & $\begin{array}{l}\text { Time to recovery from severe } \\
\text { pneumonia, tachypnoea, } \\
\text { hypoxaemia, chest indrawing } \\
\text { and fever, HLOS, treatment } \\
\text { failure, death, change of } \\
\text { antibiotics }\end{array}$ \\
\hline Brooks $2004^{(9)}$ & $\begin{array}{l}\text { Bangladesh } \\
23 \text { August 1990- } \\
19 \text { August } 2001\end{array}$ & $\begin{array}{l}\text { 135/135 } \\
9.5(\mathrm{MD} \mathrm{6} 6.2) / 9.6(\mathrm{MD} \mathrm{6.0)} \\
10.1(\mathrm{MD} \mathrm{1.1)/10.1(MD} \mathrm{1.0)}\end{array}$ & $\begin{array}{l}38 \cdot 5 / 36 \cdot 3 \\
59 \cdot 2 / 71 \cdot 1\end{array}$ & $\begin{array}{l}\text { Ampicillin + gentamicin } \\
\text { intravenously }\end{array}$ & $20 \mathrm{mg} / \mathrm{d}$ until discharge & Placebo & $\begin{array}{l}\text { Time to recovery from severe } \\
\text { pneumonia, tachypnoea, } \\
\text { hypoxaemia and chest } \\
\text { indrawing, HLOS, treatment } \\
\text { failure, death, change of } \\
\text { antibiotics and vomiting }\end{array}$ \\
\hline $\begin{array}{l}\text { Sempertegui } \\
2014^{(17)}\end{array}$ & $\begin{array}{l}\text { Ecuador } \\
\text { February 2008- } \\
\text { April } 2010\end{array}$ & $\begin{array}{l}\text { 225/225 } \\
13 \cdot 1 \text { (MD 10.3)/13.0 (MD 11.3) } \\
76.4(\mathrm{MD} 27 \cdot 2) / 74.2(\mathrm{MD} 24.9) \\
(\mu \mathrm{g} / \mathrm{dl})\end{array}$ & $\begin{array}{l}16 / 15 \cdot 1 \\
53 \cdot 3 / 55 \cdot 1\end{array}$ & $\begin{array}{l}\text { Ampicillin ( }<2 \text { years }) / \\
\text { penicillin }(\geq 2 \text { years }) \\
\text { intravenously }\end{array}$ & $20 \mathrm{mg} / \mathrm{d}$ until discharge & Placebo & $\begin{array}{l}\text { Time to recovery from severe } \\
\text { pneumonia, tachypnoea, } \\
\text { hypoxaemia and chest } \\
\text { indrawing, treatment failure, } \\
\text { death, change of antibiotics } \\
\text { and deterioration }\end{array}$ \\
\hline Shah $2012^{(16)}$ & $\begin{array}{l}\text { Nepal } \\
\text { June 2008- } \\
\text { August } 2009\end{array}$ & $\begin{array}{l}64 / 53 \\
\quad 9 \text { (IQR 5.0-14.7)/10 (IQR } \\
6 \cdot 0-18 \cdot 5) \\
\text { NR }\end{array}$ & $\begin{array}{l}67 \cdot 2 / 74 \cdot 5 \\
67 / 62 \cdot 3\end{array}$ & $\begin{array}{l}\text { Cefotaxime }+ \text { gentamicin } \\
\text { (age }<1 \text { year)/cefotaxime } \\
(>1 \text { year) intravenously }\end{array}$ & $20 \mathrm{mg} / \mathrm{d}$ for $7 \mathrm{~d}$ & Placebo & $\begin{array}{l}\text { Time to recovery from severe } \\
\text { pneumonia, hypoxaemia, } \\
\text { HLOS, treatment failure and } \\
\text { change of antibiotics }\end{array}$ \\
\hline $\begin{array}{r}\text { Srinivasan } \\
2012^{(13)}\end{array}$ & $\begin{array}{l}\text { Uganda } \\
\text { September 2006- } \\
\text { March } 2007\end{array}$ & $\begin{array}{l}\text { 176/176 } \\
\quad 17 \cdot 9 \text { (MD 12.2)/18.1 (MD 11.8) } \\
\text { 4.4 (IQR 1.3-8.0)/4.8 (IQR } \\
2 \cdot 3-10 \cdot 4)\end{array}$ & $\begin{array}{l}\text { NR/NR } \\
55 \cdot 7 / 56 \cdot 8\end{array}$ & $\begin{array}{l}\text { Chloramphenicol or } \\
\text { ceftriaxone intravenously } \\
\text { for } 7 d\end{array}$ & $\begin{array}{l}10 \mathrm{mg}(<12 \text { months }) / \\
20 \mathrm{mg}(\geq 12 \text { months }) / \mathrm{d} \\
\text { for a maximum of } 7 \mathrm{~d}\end{array}$ & Placebo & $\begin{array}{l}\text { Time to recovery from } \\
\text { tachypnoea, hypoxaemia, } \\
\text { fever and death }\end{array}$ \\
\hline Valavi $2011^{(10)}$ & $\begin{array}{l}\text { Iran } \\
\text { December 2008- } \\
\text { January } 2009\end{array}$ & $\begin{array}{l}64 / 64 \\
15 \cdot 41 / 15 \cdot 89 \\
\text { NR }\end{array}$ & $\begin{array}{l}\text { NR/NR } \\
54 \cdot 1 / 51 \cdot 6\end{array}$ & $\begin{array}{l}\text { Ampicillin/intravenous } \\
\text { cefazolin (staphylococcal } \\
\text { pneumonia) intravenously }\end{array}$ & $\begin{array}{l}2 \mathrm{mg} / \mathrm{kg} \text { per } \mathrm{d}, \text { maximum } \\
20 \mathrm{mg} / \mathrm{d} \text { for } 5 \mathrm{~d}\end{array}$ & Placebo & $\begin{array}{l}\text { Time to recovery from severe } \\
\text { pneumonia, tachypnoea, } \\
\text { fever and HLOS }\end{array}$ \\
\hline \multirow[t]{2}{*}{$\begin{array}{l}\text { Valentiner-Branth } \\
2010^{(15)}\end{array}$} & $\begin{array}{l}\text { Nepal } \\
1 \text { January } 2004- \\
30 \text { June } 2007\end{array}$ & $\begin{array}{l}55 / 56 \\
\quad 4(\text { IQR 3-6)/4 (IQR 3-6) } \\
\quad 8 \cdot 1(\mathrm{MD} 2 \cdot 9) / 8 \cdot 9 \text { (MD 2.2) }\end{array}$ & $\begin{array}{l}89 / 88 \\
58 / 64\end{array}$ & $\begin{array}{l}\text { Benzylpenicillin } \\
\text { intravenously for } 3 \mathrm{~d} / \text { oral } \\
\text { amoxycillin for a total of } 5 \\
\text { more days }\end{array}$ & $10 \mathrm{mg} / \mathrm{d}$ for $14 \mathrm{~d}$ & Placebo & $\begin{array}{l}\text { Time to recovery from severe } \\
\text { pneumonia, HLOS, treatment } \\
\text { failure }\end{array}$ \\
\hline & & $\begin{array}{l}\text { 19/19 } \\
16 \text { (IQR 14-26)/16 (IQR 13-22) } \\
13 \text { (MD 13)/7.9 (MD 1.5) }\end{array}$ & $\begin{array}{l}84 / 84 \\
42 / 68\end{array}$ & & $20 \mathrm{mg} / \mathrm{d}$ for $14 \mathrm{~d}$ & & \\
\hline Wadhwa $2013^{(11)}$ & $\begin{array}{l}\text { India } \\
\text { February 2007- } \\
\text { March } 2010\end{array}$ & $\begin{array}{l}\text { 274/276 } \\
5.5(\text { IQR 3-10)/5 (IQR 3-10) } \\
9.3(\text { MD 3.9)/9.2 (MD 3.6) }\end{array}$ & $\begin{array}{l}54 \cdot 7 / 54 \cdot 7 \\
64 \cdot 2 / 70 \cdot 3\end{array}$ & $\begin{array}{c}\text { Ampicillin + aminoglycoside } \\
\text { (severe)/third generation } \\
\text { cephalosporin (very } \\
\text { severe) intravenously }\end{array}$ & $\begin{array}{l}20 \mathrm{mg} / \mathrm{d} \text { until recovery or } \\
\text { for a maximum of } 14 \mathrm{~d}\end{array}$ & Placebo & $\begin{array}{l}\text { Time to recovery from severe } \\
\text { pneumonia, treatment failure } \\
\text { death, change of antibiotics } \\
\text { and deterioration }\end{array}$ \\
\hline
\end{tabular}

NR, not reported; HLOS, hospital length of stay. 


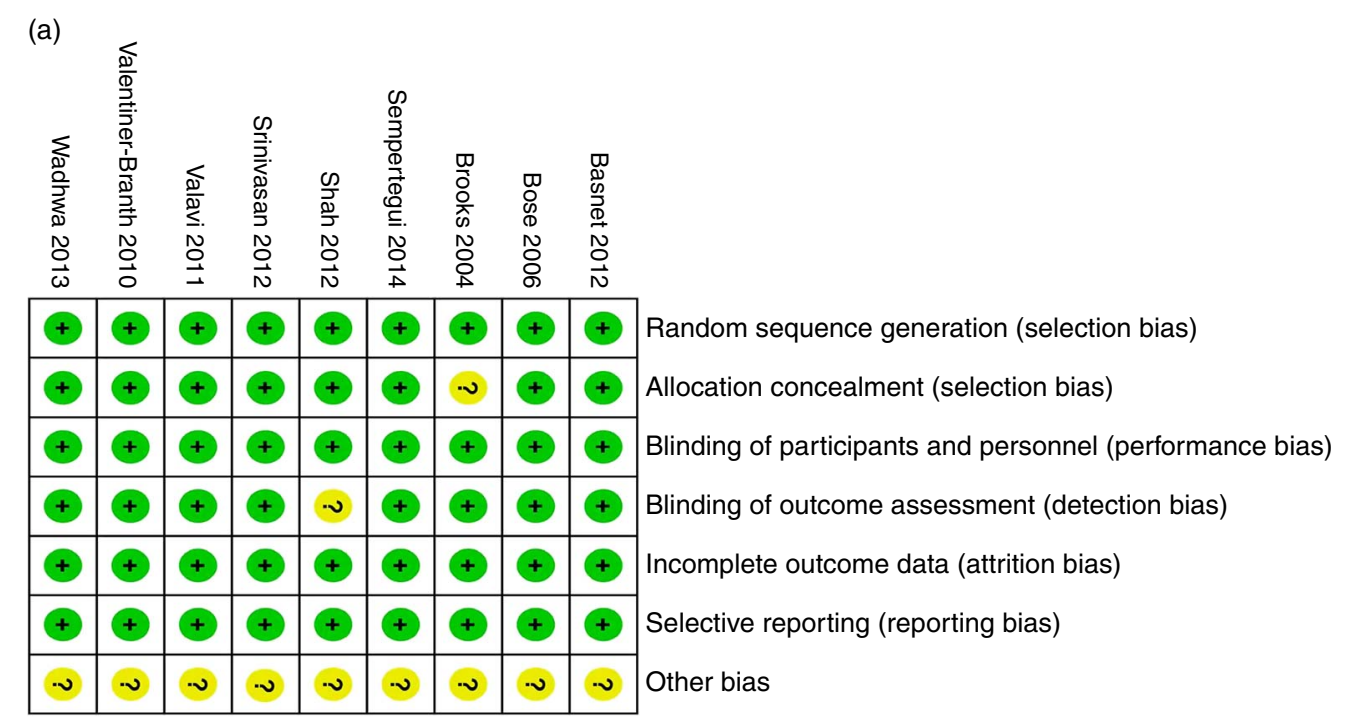

(b)

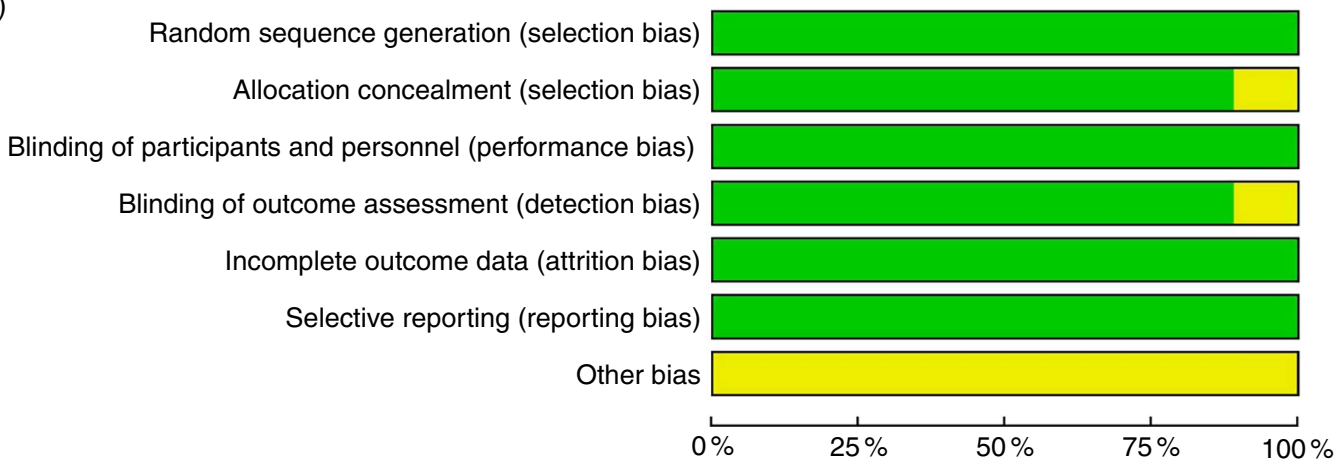

Fig. 2. Risk of bias of the included randomised-controlled trial (RCT). (a) Reviewers' judgments about each risk of bias item; (b) each risk of bias item presented as percentages. $\square$, Low risk of bias; $\square$, unclear risk of bias.

decrease potential heterogeneity. In addition, the heterogeneities in outcomes of time to recovery from tachypnoea $\left(I^{2}=77 \%\right)$, time to recovery from fever $\left(I^{2}=77 \%\right)$ and change of antibiotics $\left(I^{2}=52 \%\right)$ were statistically significant, and thus it was not appropriate to use a fixed-effects model for metaanalysis. Furthermore, the previous meta-analysis ${ }^{(27)}$ used SMD and $95 \% \mathrm{CI}$ for continuous outcomes (time to recovery), and it would be more appropriate to treat them as time-to-event data and calculate with HR and $95 \%$ CI. For dichotomous outcomes, $\mathrm{RR}$, rather than $\mathrm{OR}$, should be used, as the event rates were relatively high in the included RCT.

Another meta-analysis conducted by Theodoratou et al. ${ }^{(28)}$ was praised to express intervention effect as HR with 95\% CI. However, only two studies with 463 children were included. Moreover, it is unreasonable to exclude children with wheezing in the study by Brooks et al. ${ }^{(9)}$, as wheezing is a common sign of severe pneumonia in children ${ }^{(29)}$. Furthermore, significant heterogeneity was observed in all outcomes. A Cochrane review was also performed to assess the adjunct effect of $\mathrm{Zn}$ in the treatment of severe pneumonia. Nevertheless, only four RCT were included, and three of them were involved in quantitative analysis ${ }^{(30)}$. The author found that adjunct treatment with $\mathrm{Zn}$ failed to reduce time to recovery from severe pneumonia ( $\mathrm{HR}=1 \cdot 12 ; 95 \%$ CI $0.89,1.41)$ by combining two studies with 408 children or HLOS (HR=1.04; 95\% CI 0.89, 1.22 ) by pooling three studies with 707 children. However, substantial heterogeneity was observed $\left(I^{2}=73 \% ; P_{H}=0.05\right.$ and $I^{2}=56 \% ; P_{H}=0 \cdot 1$, respectively) and inappropriate fixedeffect model was used. Considering the statistical heterogeneity, random-effects model should be used to give a wider CI. In both previous meta-analyses ${ }^{(28,30)}$, clinical outcomes such as treatment failure, changes of antibiotics, death rate and adverse events were not analysed.

Our study generally agreed with and further extended the previous meta-analyses ${ }^{(27,28,30)}$ in several important aspects. We particularly appraised the effect of $\mathrm{Zn}$ as an adjunct to antibiotics in children with severe pneumonia and reinforced the earlier results ${ }^{(30)}$ by adding six new RCT with 2207 cases. In our study, the outcomes of time to recovery were meta-analysed as time-to-event data (HR), and the results were consistent with the pooled estimates when analysed as continuous variables (SMD). The consistency undoubtedly consolidated our results. Moreover, sensitivity analysis was performed for the primary outcomes, and intention-to-treat analysis was used for all outcomes, and the null association still remained stable. Furthermore, other meaningful outcomes, such as treatment failure, change of antibiotics, death, vomiting and clinical deterioration, were also analysed. 
$\mathrm{HR}$

Study $\log (\mathrm{HR})$

SE Weight IV, Random, $95 \% \mathrm{Cl}$

$\mathrm{HR}$

(a) Time to recovery from severe pneumonia

Basnet (2012)

Bose (2006)

Brooks (2004)

$-0.15082287$

$0.08271419 \quad 31.0 \%$

0.08271419

$13.8 \%$

(0.94, 1.29)

Valentiner-Branth (2010)

0.35767441

0.16661783

$13.5 \%$

$0.86(0.62,1.19)$

$-0.09431065$

0.16909

Wadhwa (2013)

$-0.02020269$

$13.2 \%$

$1.43(1.03,1.98)$

$0.91(0.65,1.27)$

$0.98(0.82,1.17)$

Subtotal $(95 \% \mathrm{Cl})$

$0.09067721 \quad 28.5 \%$

$1.04(0.90,1.19)$

Heterogeneity: $\tau^{2}=0.01 ; \chi^{2}=6.50, \mathrm{df}=4(P=0.16) ; I^{2}=39 \%$

Test for overall effect: $Z=0.55(P=0.58)$

(b) HLOS

Bose (2006)

Brooks (2004)

Valentiner-Branth (2010)

\section{$-0.07257069$ \\ 0.28517897 \\ $-0.09431065$}

$0 \cdot 11686449$

$100 \cdot 0 \%$

$0 \cdot 14022078$

$38.6 \%$

$0.93(0.74,1.17)$

$33.5 \% \quad 1.33(1.01,1.75)$

$28.0 \% \quad 0.91(0.65,1.27)$

Subtotal $(95 \% \mathrm{Cl})$

$100.0 \%$

$1.04(0.82,1.33)$

Heterogeneity: $\tau^{2}=0.03 ; \chi^{2}=4.61, \mathrm{df}=2(P=0.10) ; I^{2}=57 \%$

Test for overall effect: $Z=0.33(P=0.74)$

Study

Experimental

Control Events Total Events Total

Weight $\mathrm{M}-\mathrm{H}$, Random, $95 \% \mathrm{Cl}$

IV, Random, $95 \%$ Cl

(c) Treatment failure

Basnet (2012)

Brooks (2004)

Sempertegui (2014)

Shah (2012)

Valentiner-Branth (2010)

Wadhwa (2013)

Subtotal $(95 \% \mathrm{Cl})$

Total events

\begin{tabular}{rr}
98 & 29 \\
3 & 13 \\
76 & 22 \\
15 & 6 \\
14 & 73 \\
37 & 274 \\
& 105 \\
\hline
\end{tabular}

296
132
220
64
73
274
1059

$111 \quad 298$

$10-131$

131

221

76

53

16
14

72

276

255

$1051 \quad 100 \cdot 2 \%$

$0.89(0.71,1 \cdot 11)$

$0.30(0.08,1.06)$

$1.00(0.78,1.30)$

$0.78(0.42,1.42)$

$0.99(0.51,1.92)$

$1.33(0.84,2 \cdot 11)$

$0.95(0.79,1.14)$

Heterogeneity: $\tau^{2}=0.01 ; \chi^{2}=6.25, \mathrm{df}=5(P=0.28) ; I^{2}=20 \%$

Test for overall effect: $Z=0.56(P=0.58)$

(d) Change of antibiotics

$\begin{array}{lrrrr}\text { Bose (2006) } & 45 & 150 & 34 & 149 \\ \text { Brooks (2004) } & 3 & 132 & 10 & 131 \\ \text { Sempertegui (2014) } & 56 & 220 & 52 & 221 \\ \text { Shah (2012) } & 15 & 64 & 16 & 53 \\ \text { Wadhwa (2013) } & 31 & 274 & 22 & 276 \\ \text { Subtotal (95\% Cl) } & & 840 & & 830 \\ \text { Total events } & 150 & & 134 \\ \text { Heterogeneity: } \tau^{2}=0 \cdot 05 ; \chi^{2}=7 \cdot 14, \mathrm{df}=4(P=0 \cdot 13) ; I^{2}=44 \% \\ \text { Test for overall effect: } Z=0.42(P=0 \cdot 67)\end{array}$

$27 \cdot 3 \%$

$5.1 \%$

$30.9 \%$

$16.6 \%$

$20.0 \%$

$100 \cdot 0 \%$

$1.31(0.90,1.93)$

$0.30(0.08,1.06)$

$1.08(0.78,1.50)$

$0.78(0.42,1.42)$

$1.42(0.84,2 \cdot 39)$

$1.07(0.79,1.45)$

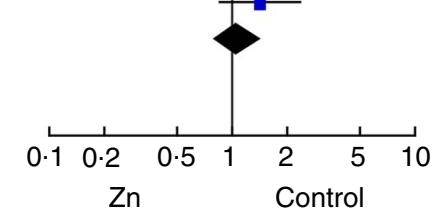

Fig. 3. Forest plots of the effects of zinc as an adjunct to antibiotics on outcomes of (a) time to recovery from severe pneumonia, (b) HLOS, (c) treatment failure and (d) change of antibiotics. HLOS, hospital length of stay; HR, hazard ratio.

Table 2. The pooled results of continuous variable as standard mean differences (SMD) (95\% confidence intervals)

\begin{tabular}{|c|c|c|c|c|c|c|c|}
\hline Outcomes & Number of trials & Number of patients & $I^{2}(\%)$ & $P_{H}$ & SMD & $95 \% \mathrm{Cl}$ & $P$ \\
\hline \multicolumn{8}{|l|}{ Primary outcomes } \\
\hline Time to recovery from severe pneumonia $(9,10,12-17)$ & 8 & 2447 & 81 & $<0.001$ & -0.02 & $-0.21,0.17$ & 0.82 \\
\hline $\operatorname{HLOS}(9,10,14-16)$ & 5 & 947 & 75 & 0.001 & -0.14 & $-0 \cdot 42,0 \cdot 13$ & 0.31 \\
\hline \multicolumn{8}{|l|}{ Secondary outcomes } \\
\hline Time to recovery from tachypnoea $(9-11,14,17)$ & 5 & 1439 & 75 & 0.003 & -0.11 & $-0 \cdot 33,0 \cdot 10$ & 0.3 \\
\hline Time to recovery from hypoxaemia $(9,11,14,16,17)$ & 5 & 1414 & 0 & 0.41 & 0.03 & $-0.07,0.14$ & 0.53 \\
\hline Time to recovery from chest indrawing $(9,14,17)$ & 3 & 961 & 14 & 0.31 & -0.07 & $-0.20,0.07$ & 0.33 \\
\hline Time to recovery from fever $(10,11,14)$ & 3 & 774 & 68 & 0.05 & -0.14 & $-0.40,0.12$ & 0.29 \\
\hline
\end{tabular}

$P_{H}, P$ for heterogeneity. 
Table 3. The results of sensitivity analysis for the primary outcomes

(Hazard ratios (HR), standard mean difference (SMD), relative risk (RR) and $95 \%$ confidence intervals)

\begin{tabular}{|c|c|c|c|c|c|c|c|c|}
\hline Outcome & ES (min) & $95 \% \mathrm{Cl}$ & $I^{2}(\%)$ & $P$ & ES (max) & $95 \% \mathrm{Cl}$ & $I^{2}(\%)$ & $P$ \\
\hline Time-to-event data & \multicolumn{8}{|c|}{$\mathrm{HR}(95 \% \mathrm{Cl})$} \\
\hline Time to recovery from severe pneumonia $(9,12-15)$ & 1.01 & $0.91,1.12$ & 0 & 0.89 & 1.07 & $0.92,1.24$ & 40 & 0.36 \\
\hline HLOS $(9,14,15)$ & 0.92 & $0.76,1.11$ & 0 & 0.41 & $1 \cdot 11$ & $0.77,1.61$ & 66 & 0.57 \\
\hline Continuous variables & \multicolumn{8}{|c|}{ SMD (95\% Cl) } \\
\hline Time to recovery from severe pneumonia $(9,10,12-17)$ & -0.08 & $-0.27,0.10$ & 77 & 0.36 & 0.05 & $-0.10,0.21$ & 68 & 0.48 \\
\hline $\operatorname{HLOS}(9,10,14-16)$ & -0.18 & $-0.51,0.14$ & 79 & $0 \cdot 26$ & -0.00 & $-0.14,0.14$ & 0 & 1 \\
\hline Dichotomous variables & \multicolumn{8}{|c|}{$\mathrm{RR}(95 \% \mathrm{Cl})$} \\
\hline Treatment failure $(9,12,13,15-17)$ & 0.91 & $0.78,1.06$ & 0 & $0 \cdot 24$ & 0.97 & $0.74,1.28$ & 29 & 0.85 \\
\hline Change of antibiotics $(9,12,14,16,17)$ & 0.96 & $0.64,1.45$ & 51 & 0.86 & $1 \cdot 15$ & $0.93,1.42$ & 0 & 0.19 \\
\hline
\end{tabular}

ES, effect size; min, minimum; max, maximum; HR, hazard ratios; HLOS, hospital length of stay; SMD, standard mean difference; RR, relative risk.

HR HR

Study $\quad \log (\mathrm{HR}) \quad$ SE $\quad$ Weight $\quad$ IV, Random, $95 \% \mathrm{Cl} \quad \mathrm{IV}, \mathrm{Random}, 95 \% \mathrm{Cl}$

(a) Time to recovery from tachypnea

Bose (2006)

Brooks (2004)

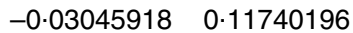

$0.30010461 \quad 0.13770744$

$-0.12783338 \quad 0.12583707 \quad 33.5 \%$

$35.1 \%$

$31 \cdot 4 \%$

Srinivasan (2012)

$100 \cdot 0 \%$

Heterogeneity: $\tau^{2}=0.03 ; \chi^{2}=5.69, \mathrm{df}=2(P=0.06) ; l^{2}=65 \%$

Test for overall effect: $Z=0.33(P=0.74)$

(b) Time to recovery from hypoxemia

Bose (2006)

Brooks (2004)

Srinivasan (2012)

$-0.06187541 \quad 0.11903558$

$0.23901689 \quad 0.1366118$

$0.03922068 \quad 0.17335243$

Subtotal $(95 \% \mathrm{Cl})$

Heterogeneity: $\tau^{2}=0.01 ; \chi^{2}=2 \cdot 78, \mathrm{df}=2(P=0.25) ; I^{2}=28 \%$

Test for overall effect: $Z=0.69(P=0.49)$

(c) Time to recovery from chest indrawing

Bose (2006)

Brooks (2004)

$-0.08338159 \quad 0.14171578$

$0.22314355 \quad 0.13928305$

$49.6 \%$

$50.4 \%$

Subtotal $(95 \% \mathrm{Cl})$

$100 \cdot 0 \%$

Heterogeneity: $\tau^{2}=0.03 ; \chi^{2}=2 \cdot 38, \mathrm{df}=1(P=0.12) ; I^{2}=58 \%$

Test for overall effect: $Z=0.46(P=0.64)$

(d) Time to recovery from fever

Bose (2006)

Srinivasan (2012)

$-0.06187541 \quad 0.11903558$

$53 \cdot 3 \%$

$0.01587338 \quad 0.12706289$

$46 \cdot 7 \%$

$100 \cdot 0 \%$

Heterogeneity: $\tau^{2}=0.00 ; \chi^{2}=0.20, d f=1(P=0.66) ; l^{2}=0 \%$

Test for overall effect: $Z=0.29(P=0.77)$
$0.92(0 \cdot 70,1 \cdot 21)$

$1.25(0.95,1.64)$

$1.07(0.80,1.45)$

$0.94(0.74,1 \cdot 19)$

$1.27(0.97,1.66)$

$1.04(0.74,1.46)$

$1.07(0.89,1.29)$

$0.94(0.74,1 \cdot 19)$

$1.02(0.79,1 \cdot 30)$

$0.97(0.82,1.16)$

$1.35(1.03,1.77)$
$0.88(0.69,1.13)$

$1 \cdot 04(0 \cdot 82,1 \cdot 33)$

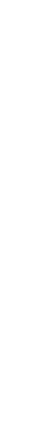

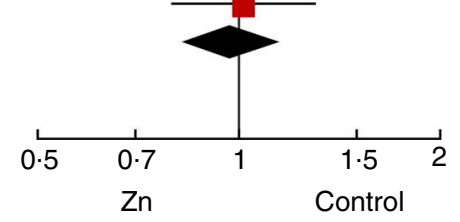

Fig. 4. Forest plots of the effects of zinc as an adjunct to antibiotics on outcomes of (a) time to recovery from tachypnoea, (b) hypoxaemia, (c) chest indrawing and (d) fever. HR, hazard ratio.

\section{Potential mechanism}

Zn has a crucial role in immune response, including the activation of polymorphonuclear cells, macrophages, natural killer cells, $\mathrm{T}$ cell, antibody production, the balance of $\mathrm{T}$ helper lymphocyte and immune defence-specific protein synthesis ${ }^{(9,31)}$. Plasma $\mathrm{Zn}$ decreases during the acute phase response because of the mobilisation and sequestration of $\mathrm{Zn}$ to metallothionein ${ }^{(32)}$, and hence $\mathrm{Zn}$ supplementation in the treatment of severe pneumonia might be associated with a robust immune response and consequently a better prognosis. However, no effect of $\mathrm{Zn}$ in the treatment of severe pneumonia was observed in current meta-analysis. It might be explained by the following hypotheses. First, respiratory system, different from the digestive system, is sterile below the larynx in normal circumstance, and tissue damage could be caused by $\mathrm{Zn}$-induced robust host response ${ }^{(33)}$. 


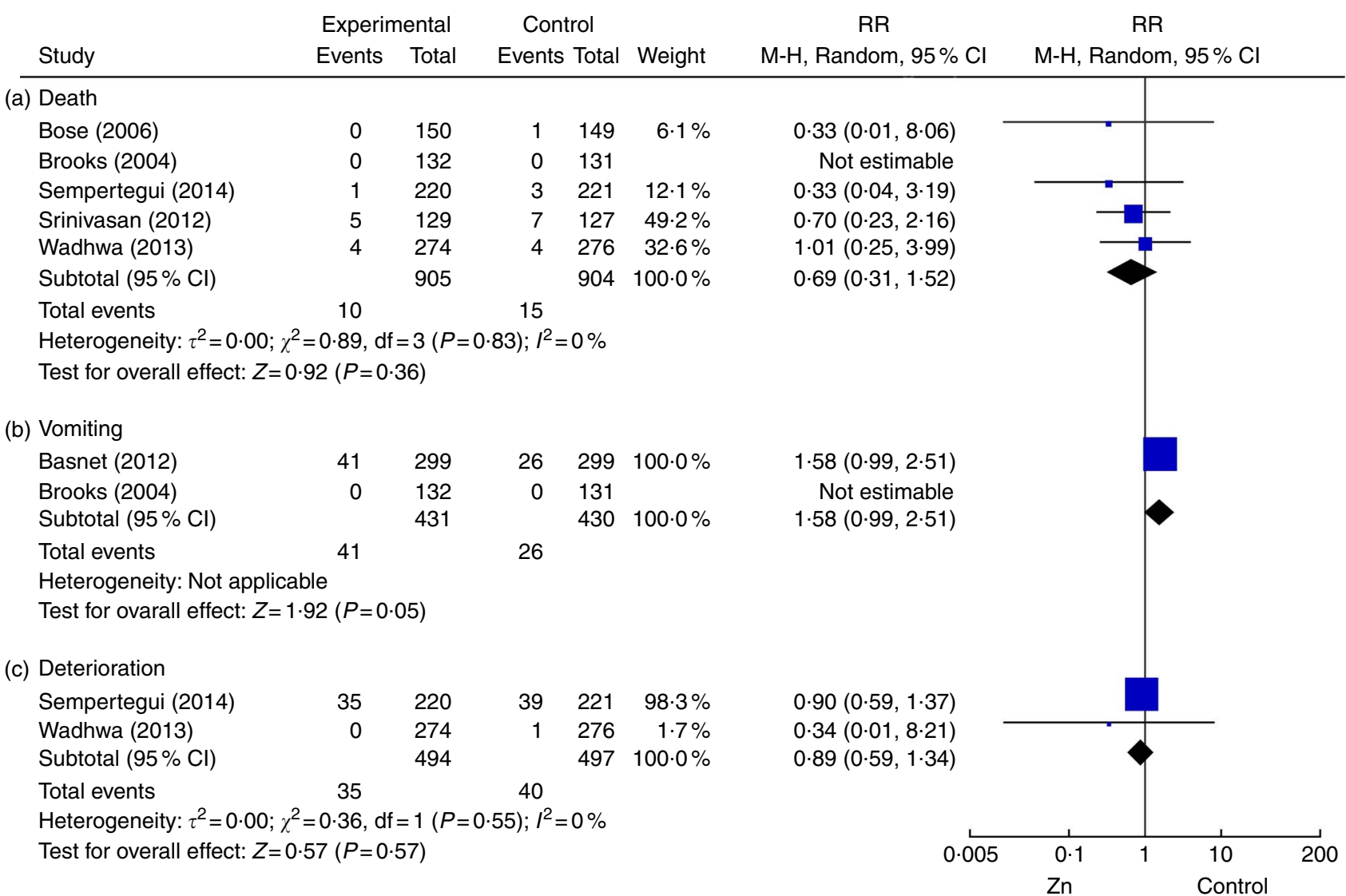

Fig. 5. Forest plots of the effects of zinc as an adjunct to antibiotics on outcomes of (a) death rate, (b) vomiting and (c) deterioration. RR, relative risk.

Thus, the decreased inflammatory signs might actually favour the clinical recovery of severe pneumonia ${ }^{(34)}$. Second, $\mathrm{Zn}$ might exacerbate the situation by the increased pro-inflammation while eradicating infection. Consistently, it was reported that $\mathrm{Zn}$ could decrease the case fatality and treatment failure without improving clinical recovery ${ }^{(11,35)}$, indicating that the benefit of $\mathrm{Zn}$ might be counteracted or alleviated by the detrimental effect from increased pro-inflammation. Third, the duration of $\mathrm{Zn}$ supplementation was relatively short, and the impaired immune response could not be reversed by such a short-time supplementation $^{(17)}$. Finally, the varied results from studies and subgroup analyses ${ }^{(9-17)}$ could be attributed to the differences in population characteristics, intervention of $\mathrm{Zn}$ supplementation, outcome measures and location and period of the study, all of which could confound the effect of $\mathrm{Zn}$ in the treatment of severe pneumonia.

\section{Limitations}

Several limitations should be taken into account. First, several studies expressed the primary outcomes of time to recovery from severe pneumonia and HLOS as continuous variables. Although corresponding authors were contacted repeatedly, results from time-to-event analysis were not obtained in several RCT. The missing data might also induce bias, but the results obtained by pooling HR with $95 \%$ CI were consistent with that obtained from pooling SMD with 95\% CI. Second, significant heterogeneity was found in HLOS and secondary outcomes. To test the robustness of results, sensitivity analysis and intentionto-treat analysis were used, and all the results remained consistent. Third, age, sex and nutrition status of children ${ }^{(9,10,17)}$, the aetiology, definition, severity and recovery criteria of severe pneumonia $^{(9,12,13)}$, the dose, timing and duration of $\mathrm{Zn}$ supplementation and the location and season of study ${ }^{(10,14)}$ have been reported to influence the effect of $\mathrm{Zn}$ in treatment of severe pneumonia. However, subgroup analysis was not performed because of the limited number of included studies.

\section{Future direction}

Some valuable evidence could be obtained from our metaanalysis. Both previous researches and our results demonstrated that Zn supplementation could increase the incidence of vomiting. However, it is usually limited and slight, and thus proper dose of $\mathrm{Zn}$ should be recommended without much concern about the increasing incidence of vomiting. Although there was a reduction of $31 \%$ case-fatality rate in the $\mathrm{Zn}$ group, no statistical significance was observed. As only twenty-five deaths were involved, low statistical power might be attributed to, and high-quality and large-scale RCT are still needed. In addition, future studies should take nutrition status of children, breast-feeding time, aetiology of pneumonia, the dose, timing and duration of $\mathrm{Zn}$ supplementation into consideration. Moreover, clinical outcomes of vomiting, feeding difficulty, clinical 
deterioration and need for intensive care should also be evaluated.

\section{Conclusion}

In conclusion, our meta-analysis suggested that adjunct treatment with $\mathrm{Zn}$ failed to show beneficial effect for the treatment of severe pneumonia in children $<5$ years old. However, this conclusion should be interpreted cautiously because of clinical heterogeneity across studies, and high-quality and large-scale RCT are still needed before making any definite conclusion. In addition, some confounding factors and valuable clinical outcomes should also be considered.

\section{Acknowledgement}

This study was supported by the fund of the National Nature Science Foundation of China (no. 81370744) and the subproject of the National Science \& Technology Pillar Program during the twelfth Five-year Plan in China (no. 2012BAI04B05).

The authors' responsibilities were as follows: H.-T. T. designed the conception, conducted the search, collected the data, assessed the quality of included studies, analysed and interpreted the data and drafted the manuscript. Q. T. conducted the search, assessed the quality of included studies, analysed and interpreted the data and revised the intellectual content. M.-Z. L. collected the data, assessed the quality of included studies and conducted the statistical analysis. Q. L. collected the data and revised the intellectual content. J.-L. Y. designed the conception, analysed and interpreted the data and revised the intellectual content. Q.-C. W designed the conception, analysed and interpreted the data and revised the intellectual content. All authors read and approved the final manuscript.

The authors declare that there are no conflicts of interest.

\section{Supplementary material}

For supplementary material/s referred to in this article, please visit http://dx.doi.org/doi:10.1017/S0007114515005449

\section{References}

1. Scott JA, Brooks WA, Peiris JS, et al. (2008) Pneumonia research to reduce childhood mortality in the developing world. J Clin Invest 118, 1291-1300.

2. Liu L, Oza S, Hogan D, et al. (2015) Global, regional, and national causes of child mortality in 2000-13, with projections to inform post-2015 priorities: an updated systematic analysis. Lancet 385, 430-440.

3. Bryce J, Black RE \& Victora CG (2013) Millennium Development Goals 4 and 5: progress and challenges. BMC Med 11, 225.

4. Scrimshaw NS \& SanGiovanni JP (1997) Synergism of nutrition, infection, and immunity: an overview. Am J Clin Nutr 66, 464S-477S.

5. Caulfield LE, de Onis M, Blossner M, et al. (2004) Undernutrition as an underlying cause of child deaths associated with diarrhea, pneumonia, malaria, and measles. Am J Clin Nutr 80, 193-198.

6. Basnet S, Mathisen M \& Strand TA (2014) Oral zinc and common childhood infections - an update. J Trace Elem Med Biol 31, 163-166.

7. Black RE \& Sazawal S (2001) Zinc and childhood infectious disease morbidity and mortality. Br j Nutr 85, S125-S129.

8. Shankar AH \& Prasad AS (1998) Zinc and immune function: the biological basis of altered resistance to infection. Am J Clin Nutr 68, 447S-463S.

9. Brooks WA, Yunus M, Santosham M, et al. (2004) Zinc for severe pneumonia in very young children: double-blind placebo-controlled trial. Lancet 363, 1683-1688.

10. Valavi E, Hakimzadeh M, Shamsizadeh A, et al. (2011) The efficacy of zinc supplementation on outcome of children with severe pneumonia. A randomized double-blind placebo-controlled clinical trial. Indian $J$ Pediatr $\mathbf{7 8}$, 1079-1084

11. Wadhwa N, Chandran A, Aneja S, et al. (2013) Efficacy of zinc given as an adjunct in the treatment of severe and very severe pneumonia in hospitalized children $2-24$ mo of age: a randomized, double-blind, placebo-controlled trial. Am J Clin Nutr 97, 1387-1394.

12. Basnet S, Shrestha PS, Sharma A, et al. (2012) A randomized controlled trial of zinc as adjuvant therapy for severe pneumonia in young children. Pediatrics 129, 701-708.

13. Srinivasan MG, Ndeezi G, Mboijana CK, et al. (2012) Zinc adjunct therapy reduces case fatality in severe childhood pneumonia: a randomized double blind placebo-controlled trial. BMC Med 10, 14

14. Bose A, Coles CL, Gunavathi, et al. (2006) Efficacy of zinc in the treatment of severe pneumonia in hospitalized children $<2$ y old. Am J Clin Nutr 83, 1089-1096.

15. Valentiner-Branth P, Shrestha PS, Chandyo RK, et al. (2010) A randomized controlled trial of the effect of zinc as adjuvant therapy in children 2-35 mo of age with severe or nonsevere pneumonia in Bhaktapur, Nepal. Am J Clin Nutr 91, $1667-1674$.

16. Shah GS, Dutta AK, Shah D, et al. (2012) Role of zinc in severe pneumonia: a randomized double bind placebo controlled study. Ital J Pediatr 38, 36.

17. Sempertegui F, Estrella B, Rodriguez O, et al. (2014) Zinc as an adjunct to the treatment of severe pneumonia in Ecuadorian children: a randomized controlled trial. Am J Clin Nutr 99, 497-505.

18. Moher D, Liberati A, Tetzlaff J, et al. (2009) Preferred reporting items for systematic reviews and meta-analyses: the PRISMA statement. BMJ 339, 2535.

19. Higgins JPT \& Green S. (2008) Cochrane Handbook for Systematic Reviews of Interventions, vol 5. Wiley Online Library.

20. Higgins JP, Altman DG, Gotzsche PC, et al. (2011) The Cochrane Collaboration's tool for assessing risk of bias in randomised trials. BMJ 343, d5928.

21. Hozo SP, Djulbegovic B \& Hozo I (2005) Estimating the mean and variance from the median, range, and the size of a sample. BMC Med Res Methodol 5, 13 .

22. Higgins JP, Thompson SG, Deeks JJ, et al. (2003) Measuring inconsistency in meta-analyses. BMJ 327, 557-560.

23. Shah G (2014) Role of zinc in severe pneumonia: a randomized double bind placebo controlled study. Pediatr Pulmonol 49, S81.

24. Bansal A, Parmar VR, Basu S, et al. (2011) Zinc supplementation in severe acute lower respiratory tract infection in children: a triple-blind randomized placebo controlled trial. Indian J Pediatr 78, 33-37. 
25. Mahalanabis D, Lahiri M, Paul D, et al. (2004) Randomized, double-blind, placebo-controlled clinical trial of the efficacy of treatment with zinc or vitamin A in infants and young children with severe acute lower respiratory infection. Am J Clin Nutr 79, 430-436.

26. Coles CL, Bose A, Moses PD, et al. (2007) Infectious etiology modifies the treatment effect of zinc in severe pneumonia. $\mathrm{Am}$ J Clin Nutr 86, 397-403.

27. Das RR, Singh M \& Shafiq N (2012) Short-term therapeutic role of zinc in children $<5$ years of age hospitalised for severe acute lower respiratory tract infection. Paediatr Respir Rev 13, 184-191.

28. Theodoratou E, Al-Jilaihawi S, Woodward F, et al. (2010) The effect of case management on childhood pneumonia mortality in developing countries. Int J Epidemiol 39, i155-i171.

29. le Roux DM, Myer L, Nicol MP, et al. (2015) Incidence and severity of childhood pneumonia in the first year of life in a South African birth cohort: the Drakenstein Child Health Study. Lancet Global Health 3, e95-e103.
30. Haider BA, Lassi ZS, Ahmed A, et al. (2011) Zinc supplementation as an adjunct to antibiotics in the treatment of pneumonia in children 2 to 59 months of age. Cochrane Database Syst Rev CD007368.

31. Bonaventura P, Benedetti G, Albarede F, et al. (2015) Zinc and its role in immunity and inflammation. Autoimmun Rev 14, 277-285.

32. Brown KH (1998) Effect of infections on plasma zinc concentration and implications for zinc status assessment in low-income countries. Am J Clin Nutr 68, 425S-429S.

33. Tsai KS \& Grayson MH (2008) Pulmonary defense mechanisms against pneumonia and sepsis. Curr Opin Pulmonary Med 14, 260-265.

34. Mizgerd JP (2008) Acute lower respiratory tract infection. New Engl J Med 358, 716-727.

35. Bhatnagar S, Wadhwa N, Aneja S, et al. (2012) Zinc as adjunct treatment in infants aged between 7 and 120 days with probable serious bacterial infection: a randomised, doubleblind, placebo-controlled trial. Lancet 379, 2072-2078. 